\title{
LORD COOKE AND CAMBRIDGE
}

\author{
Professor A T H Smith*
}

This article seeks to explain the enduring formative influence that early life in Cambridge and at Gonville and Caius College exerted on Lord Cooke's intellectual (and social) development. It suggests that his early experiences provided something of a platform which enabled Lord Cooke to take a leading part in the subsequent development of New Zealand's separate legal identity.

When Sir Robin Cooke was elevated to the peerage in 1996, he took as his title "Baron Cooke of Thorndon in Wellington and Cambridge in the County of Cambridgeshire". The reference to Cambridge was, I believe, rather more than simply an affectionate tribute to a part of the world in which he had once been a young student and don, and of which he harboured fond memories throughout the course of his life thereafter. Like his reference to "Thorndon", ${ }^{1}$ it was intended to be a public acknowledgment of the debts (primarily intellectual, but also social) that he had contracted in the course of his experiences in Cambridge and England.

In his funeral address, Sir Michael Hardie Boys - a former Governor General of New Zealand and for a time Robin's colleague on the Court of Appeal - said that Robin ${ }^{2}$ was "a Cambridge man through and through". ${ }^{3}$ My purpose in this brief essay is to expand on that observation and to seek

* Pro Vice-Chancellor and Dean of Law, Victoria University of Wellington. I have spoken to a number of people in the course of writing what follows, and I am particularly grateful to Lady Cooke, Francis Cooke QC, Wendy Cooper (sister), Bill Shires QC and Mrs Shires, Dale Densem and Sir Gordon Bisson for their patience with my questions. I trust that I have not misrepresented their responses. I am also grateful to $\mathrm{Dr}$ Mike Wade for permitting me to have access to the correspondence between his father Sir William Wade and Robin.

1 Thorndon was chosen because it was the suburb of Wellington in which many of the most important events of his life occurred. He lived in Thorndon when young and met and married his wife there and (since it housed the law courts) spent the best part of his professional life there. It was also ultimately the place (in the Wellington Cathedral of St Paul) in which his funeral service was held, on 4 September 2006.

2 In the course of his stay in Cambridge in 1978, Robin invited me to accompany him and two New Zealand (Caius) Law research students for an after-dinner drink at the Queen's Head pub in Newton, a village just outside Cambridge. As we settled around our pints, one of the students addressed him as "judge". The gentle response was that "I might be 'Judge' in New Zealand, but in Cambridge I am 'Robin'". The student in question was Willie Young, now President of the New Zealand Court of Appeal.

3 See page 9 in this volume. 
to explain some of its significance and implications, essentially for a New Zealand audience. To adumbrate: I suspect that Robin's election to a Fellowship of Caius College afforded (or at any rate reinforced) a degree of intellectual self-confidence and independence that his educational experience hitherto had not provided. ${ }^{4}$ His time in Cambridge gave him an understanding of the United Kingdom such that, when New Zealand was forced to chart different directions in the wake of the United Kingdom's accession to the European Economic Community (as it then was) in 1973, he was able to give a legal lead that neither abandoned New Zealand's English common law heritage nor stood in thrall to it. He was uniquely well positioned to afford reassurance, to New Zealand's legal community and more widely, ${ }^{5}$ that the time had come to fashion a jurisprudence that would be unique to New Zealand, and would in practice accommodate its rapidly changing circumstances. ${ }^{6}$

Having completed his LLB in $1949^{7}$ and been awarded first class honours in the LLM at Victoria University College in 1950, the young Robin Cooke ${ }^{8}$ took up the Travelling Scholarship in Law awarded by the University of New Zealand in the same year, ${ }^{9}$ and worked his passage to England on the newly-commissioned Rangitoto in the purser's office. In those days, overseas travel by young New Zealanders was not the commonplace event it has become with the advent of the jet, and it was Robin's first time outside New Zealand.

In the preface to his doctoral thesis, Robin thanks by name only two people in addition to his supervisor. They were Professor RO McGechan ${ }^{10}$ "whose teaching first aroused my interest in

4 In "Court of Appeal President: An Interview with Sir Robin Cooke" [1986] NZLJ 170, 170 Sir Robin remarked that the transition to Cambridge was "something of a turning point in my life ... there was a serious risk that I might have stayed on permanently at Cambridge, which I found extremely attractive". Later in the same interview, he says (speaking of the origins of the other then members of the Court of Appeal "Indeed I am the only true Wellingtonian and I am just as fond of Cambridge" (177).

$5 \quad$ See Sir Robin Cooke "The Courts and Public Controversy" (1983) 5 Otago LR 357.

6 That this was being done to some extent consciously is evident from his extra-judicial writings. See Sir Robin Cooke "The New Zealand National Legal Identity" (1987) 3 Cant LR 171; "The Challenge of Treaty of Waitangi Jurisprudence" (1994) 2 Waikato LR 1.

7 At that time, undergraduate degrees were not classed. The undergraduate degree was actually completed in 1948 and the Masters in 1949, but the capping ceremonies took place in the following year, in each case, as was standard at the time.

8 He was born on 9 May 1926, and was thus 24 years of age at the time of making the journey.

9 The scholarship was awarded biennially and was held successively by Daniel O'Connell (1948), Robin Cooke (1950), Kenneth Sutton (1952), Donald Harris (1954) and Brian Coote (1956). As Sir Robin pointed out somewhat self-deprecatingly "All were to become distinguished academic lawyers, except the 1950 man, who turned into a kind of crossbreed" (1995) 9 Journal of Contract Law, 3.

10 (Dean of the Faculty) Professor McGechan died in a plane crash on 13 March 1954. He had an enormous influence on the shape of legal education at Victoria, much of which remains visible today - in particular, he initiated compulsory mooting, the Law Review in which this piece is published and (much influenced by the American experience) by the use of the Socratic method. The impetus which he gave the school was to 
administrative law" and Dr Jim Williams, who had by that time (1954) become Principal of the College. These references are a mark of the influence that Victoria had worked upon him and they give rise to questions about the legal experience that Robin enjoyed prior to his going to Cambridge. What would the Law Faculty at Wellington have been like between 1944, when Robin Cooke joined it, and when he finally graduated from there in 1950? It is difficult to give more than a brief snapshot. ${ }^{11}$

\section{THE WELLINGTON LEFT BEHIND}

Robin left school (Wanganui Collegiate) in 1943, and started at Victoria University College in 1944. His first love at school had undoubtedly been English literature, ${ }^{12}$ and for a while he considered studying that rather than the law. Perhaps because he was able to combine some study of the Arts in addition to the Law as part of the LLB degree, he went for that option. The Law Faculty at the time when the Second World War was drawing to its completion was predominantly part time, both in terms of the Faculty and the students, and predominantly male. ${ }^{13}$ For much of the war period, McGechan was the only full time member of staff. He was joined in quick succession after hostilities ceased by Dr James Williams, who arrived back in New Zealand and after a brief period of legal practice became Professor of English and New Zealand Law in 1946 at the age of 27, having completed a $\mathrm{PhD}$ at Cambridge. In the same year, ID Campbell returned as a Senior Lecturer, ${ }^{14}$ a position which he held until he succeeded Williams in 1951 upon the latter becoming Principal of the College). EK (Kingston) Braybrooke (who was a Senior Lecturer) came in 1947 before departing for Western Australia in 1955. The rest of the tuition was provided by practitioners, members of the local legal community who would probably now be described as "adjuncts".

Throughout the five years of his first degree and the year of the LLM, Robin was a part time student, working during the day for the long-established firm that is now known as Chapman Tripp, and fitting in study and lectures at either end of the day. The firm was the one in which his father

continue after his death: see his RO McGechan "A New Zealander's Comments on American Legal Education" (1953) 5 Journal of Legal Education 286; ID Campbell "Legal Writing" (1955) 1(3) VUWLR 7.

11 This section of the paper is heavily reliant upon the contents of a wonderfully combative paper, originally delivered by Professor McGechan to the Dominion Law Conference in April 1947 "The Profession and the Teaching of the Law" [1947] NZLJ 110.

12 In private conversation with me, Robin said on more than one occasion that he was not a particularly diligent student at school, preferring the running track and the boards to the books (with the exception of those relating to English literature).

13 96\% is the figure given in Rachel Barrowman Victoria University of Wellington 1899-1999 - A History (Victoria University Press, Wellington, 1999) 232.

14 Ian Campbell had been appointed Senior Lecturer in 1940, but from 1943 until 1946, he served in the Army Education Welfare service in Wellington, attaining the rank of Captain. See Dr C Aikman "In Memoriam Ian Drummond Campbell" (2001) 32 VUWLR 381. 
had been a partner ${ }^{15}$ before he took Silk in 1936 at the age of 43, and then going to the High Court Bench in March 1950. His death (after a period of illness) in November 1956 was one of the reasons why Robin decided against going back to Cambridge as an academic.

Robert Orr McGechan, who was an Australian, came to a Professorship from Sydney in 1940. He is described by Professor JC Beaglehole as "learned, accurate and intelligible". ${ }^{16}$ The LLB course was of five years duration, but a considerable portion of that was devoted to the Arts subjects. Examinations were set nationally by external examiners on behalf of the University of New Zealand, the same examination being sat at the four constituent universities, a practice which McGechan castigated as giving rise to "dull mediocrity". ${ }^{17}$ After 1941, it is true, those actually teaching the law were able to suggest draft questions to the external examiner, but even then they had to be such that they could be answered by students studying at each of the four universities. McGechan did eventually get his way, so that the teachers at each constituent Faculty were permitted to set the examinations independently, overseen by external moderators appointed by the Council of Legal Education. The numbers of undergraduates were small although there is some disagreement about just how many. Numbers were swelled by returning servicemen. To students, the cost was negligible, as no fees were payable.

One suspects that the educational provision was neither interesting nor challenging, and it was characterised by McGechan as being "a constant trend to coaching". "If you really want to bait me, to make me see red, you have only to suggest that I am even remotely interested in pushing Johnny Dullard ... through his exams. My teaching will not be devoted for a single instant to getting students extra marks in examinations. In other words, I will not coach."18

15 The firm was for a time known as Chapman, Tripp, Blair, Cooke and Watson. See Ross Gore Chapman Tripp and Co: the First Hundred Years (Chapman Tripp, Wellington, 1975) 110. The author was Robin Cooke's uncle. Even allowing for the possibility of non-objectivity to which the authorship might give rise, the picture of Philip Cooke that emerges from that book and other available sources is of an immensely gifted lawyer and public spirited man, whose career was disrupted (and his earning power diminished) by the First World War (in which he served with great distinction, winning the Military Cross), the Great Depression that crippled New Zealand in the early 1930s, and by the outbreak of the Second World War a mere 21 years after the Great War had ended. He gave up legal practice and served on the staff at Army Headquarters during the Second War. See also the tributes paid to "The Late Mr Justice Cooke" [1956] NZLJ 342 in which his concern for others, his "kindliness", is a predominant refrain.

16 JC Beaglehole Victoria University College: an Essay Towards History (Victoria University Press, Wellington, 1949) 246. This was in marked contrast to his predecessor - Adamson - who did not apparently share all of these characteristics, particularly the last mentioned, as he retained an impenetrably strong Scottish accent throughout his life.

17 RO McGechan [1947] NZLJ 110, 112.

18 Ibid, 116. In RB Cooke (ed) Portrait of a Profession (Reed, Wellington, 1969) 200, it is said that this uncompromising approach meant that "his methods were inclined to leave hard-pressed students, plunged in media res, bewildered by the complexities and vastness of the subject. Law in a nutshell was anathema to him." 
The LLM by contrast would not have been hedged about with such restrictions since it was not concerned with admission to the profession, and the numbers of students were such ${ }^{19}$ that there was the opportunity for much closer engagement between teacher and pupil. ${ }^{20}$

\section{THE TRANSITION TO CAMBRIDGE}

Although he was in later life "first and foremost a Caius man" (to quote from Sir Michael Hardie Boys' address $^{21}$ again) he originally went to Clare College as a research student. ${ }^{22}$ The preface to his dissertation indicates that his time there appears not to have been as intellectually productive as it might have been but there is no hard evidence as to why this was so. At that time, there were no Law Fellows in Clare ${ }^{23}$ and his research supervisor was at another College, Gonville and Caius. The supervisor was Professor ECS Wade, the noted expert in Constitutional (and Administrative) Law ${ }^{24}$ who was the holder of the Downing Professorship of English Laws. ${ }^{25}$ It was not (and is not) at all unusual for supervisor and student to belong to different Colleges, but the opportunities for casual social interaction between the two are considerably reduced under that arrangement.

Contact with the legal profession, of a kind that he would have enjoyed in Wellington, would not have been possible in Cambridge, which was then a small market town in the Fens, dominated by the University in its midst. There was not really a body of practising lawyers with whom he would have come into contact as he had done at home in Wellington. The practice of law was taught in London, at the Inns of Court, and by the Law Society. ${ }^{26}$

19 The Dominion newspaper for 2 February 1950 records 6 names which included in addition to Robin and $\mathrm{Mr}$ Shires (to whom I am grateful for the reference) the names of George Barton and PBA Sim, subsequently Deans of Wellington Law School and Otago respectively. Robin is reported as having taken Constitutional Law, Contract and Tort I and Shipping Law.

20 See Robin's affectionate tribute to Dr Williams [1976] NZLJ 186. This picture chimes with that given in Cooke Portrait of a Profession, above n 18, 200 where it is said that "as a teacher he was at his best with small honours classes, on the lines of an Oxford or Cambridge tutorial".

21 See above $\mathrm{n} 3$.

22 His mentor in Wellington, Dr Jim Williams, had completed his PhD at Clare, and that is almost certainly the reason why Robin went there as a student.

23 The first Law don at Clare was Bill (Later Lord) Wedderburn, who became a Fellow in 1952.

24 He was the author of ECS Wade and GG Phillips Constitutional Law first published in 1931. ECS Wade was no relation to the other great Caius public lawyer, Professor Sir HWR (William, or "Bill") Wade. Originally an undergraduate at Caius, Bill Wade became a Fellow of Trinity College Cambridge and then a Professor at St John's College Oxford, before returning to Caius as Master in 1976. A regular if sporadic correspondence was conducted between Robin and Bill, starting in at least 1977, but earlier letters may simply not have survived.

25 This was the first Chair of English Law in Cambridge, established in 1800 (the equivalent of the Vinerian Professorship at another place) and is now occupied by the legal historian Professor Sir John Baker.

26 Robin was called to the Bar by the Inner Temple in 1954. He was made an Honorary Bencher in 1985. 
The first two years in Cambridge might have been rather lonely ones, at least intellectually.

In the preface to his $\mathrm{PhD}$ dissertation, Robin charts the rather frustrating intellectual voyage in the course of which he searched for a satisfactory subject. He started with Delegated Legislation (which is what he had in mind when he left New Zealand), worked his way through what he termed "discretions" (a topic which he describes as being "relatively straightforward") and alighting eventually upon Jurisdiction. A good deal of work appears to have been undertaken on this topic, because the eventual product began life as chapter five of "discretions". The crab-like progress described in the preface will be familiar to anyone who has undertaken such a research project, as is the observation that "it is depressing to contemplate the amount of reading and note-taking not directly represented in these pages". Eventually, the thesis was written up in a period starting in Michaelmas (October) 1952 and submitted (in December 1954) as Jurisdiction; An Essay in Constitutional, Administrative and Procedural Law. The actual writing of the thesis, therefore, took some 27 months (beginning at the time when he was made a Fellow of Caius). Its quality is attested to by that fact that it won the Yorke Prize, which is awarded for dissertations ${ }^{27}$ "of distinction", in the following year. Shortly afterwards, a section of the thesis was published in the Law Quarterly Review, then as now probably the leading general scholarly English law review, under the title "Venire de Novo". ${ }^{28}$

Then, as now, the somewhat daunting rite of passage of writing a doctoral thesis gives those who are able to endure and survive it a large element of intellectual independence. The writer has to formulate a thesis, marshall the evidence in support of it and be in a position to defend every aspect of it when the time comes for examination. However eminent and knowledegable the supervisor, the student will actually find himself in a position of knowing much more than the supervisor and having to make judgments for him or herself as to all of the elements that go into the making of a doctoral thesis.

The apparent lack of progress in the early years, though, does not appear to have diminished his supervisor's regard for the abilities of the pupil. Wade was an enthusiastic advocate of Robin's

27 The prize was established with the donation of a bequest from Edmund Yorke in 1873. An early winner of the prize was Richard Maclaurin, one of the four founding Professors of Victoria University College of Wellington, who came back to New Zealand as a Professor of Mathematics in 1899. While a Fellow of St John's College in Cambridge, he took up the Law, was admitted as a Barrister and took an LLD. From the outset of his time in Wellington, he taught Law ("Jurisprudence") in addition to Mathematics, and was made the first Dean of the Law Faculty in 1907, a position he did not hold for very long, leaving first for New York (Columbia) and then becoming President of Massachusetts Institute of Technology, an institution which he is credited with having chartered the path towards the success that it now enjoys.

28 Robin Cooke "Venire de Novo" (1955) 71 LQR 100. The article was cited with approval by Lord Diplock in $R v$ Rose and Johnson [1982] AC 822, 831 (HL), who described it as "erudite" and by Lord Lane CJ earlier in the same proceedings as "an article of great scholarship" [1982] 1 WLR 614, 622 (CA). See also Judge LJ in $R v$ Poole [2001] All ER (D) 392. 
cause, and was instrumental in securing him a Fellowship at Caius, which launched Robin's career as the lawyer/scholar/judge that he was to become. The gesta of the College records that on 30 May 1952, the College Council formally recorded the intention to elect him to the Tapp Fellowship at the beginning of the succeeding academic year, and he was elected a Fellow on 10 October 1952 and admitted to the Fellowship in a ceremony in the Chapel on the same day. ${ }^{29}$ Permission was given by the College Council to engage in supervision (teaching) of students for up to six hours per week, but it was explicitly provided that Robin was not to engage in any other paid work without the permission of the College Council. I have emphasised the timing of these events, because they surround the fact that he married Annette Miller in August 1952, returning to New Zealand to do so. The pre-election to the Fellowship in May, to take effect at the beginning of the following academic year (October) would have given him a degree of financial reassurance, and made the marriage possible. Without the Fellowship, it might have been much more difficult.

This is neither the time nor the place to seek to explain the complex interrelationships between the University and its constituent colleges and faculties, but some background is important to explain the significance of the college in Cambridge University life, and what election to a Fellowship entails. Visitors to the place are often, even now, surprised by the extent to which the Faculty does not dominate its academic members' professional lives in ways that it tends to do in other (and especially New Zealand) universities. Indeed until the Norman Foster Building was opened in West Road in 1995, the Cambridge Law Faculty had no real physical home of its own members of the Faculty did not have Faculty offices in which to work and study. ${ }^{30}$ Everything centred around the College. The Colleges admitted the undergraduates (in the 1950s there were very few postgraduate students), and then taught them very intensively in small groups (of one, two or three) in "supervisions", groups which would be known here as tutorials. The Faculty would put on the lectures in rooms dotted throughout Cambridge, and examine the students at the end of the year. Attendance at the lectures was not compulsory and depended on the allure of the person giving the lectures, who might (but might well not be) the person conducting the examination at the end of the academic year. There was a University Law Library, ${ }^{31}$ where Robin would have done most of his

29 The election marked the beginning of a trend to appoint New Zealanders as Law Fellows. Robin was followed by Len Sealy of Auckland (1958) who was also Senior Tutor and Chairman of the Law Faculty. Later teaching Fellows were successively Jim Farmer, Auckland (1971); the present writer, Canterbury (1973-1982 and 1990-2006); Craig Rotherham, Canterbury (1997-2002); and Nicole Moreham, Canterbury (2003-2006). Andrew Simester (Auckland) was a Research Fellow from 1993-1996. Since the teaching complement of Law Fellows was only three or four at any one time, this predominance prompted slightly heavy handed (but essentially benign) references to "Gonville and Kiwis" amongst the remainder of the fellowship.

30 It is true even now that only about half of the members of the Faculty actually have a room in the Faculty in which to work on a daily basis; the other half work from their rooms in College.

31 From 1935, this was situated in the Cockerell building in Senate House passage which runs alongside the central part of Caius College. A 300 year cross-lease of the Library was acquired from the university by Caius in the mid 1990s when the Squire was moved to its new premises in West Road. 
work. For the student who was not an undergraduate, the whole set up was not particularly conducive to a feeling of belonging in any real sense.

On 1 October 1952, Robin became a Research Fellow of Gonville and Caius, thereby becoming a full member ${ }^{32}$ of the Cambridge legal and intellectual community. ${ }^{33}$ He now had a reasonably secure (if not princely) income and a room in College in which to base himself and to work. ${ }^{34}$ The College of which he became a Fellow was ancient, ${ }^{35}$ wealthy and an intellectual powerhouse. There were some forty Fellows, and it was a group of very distinguished men. ${ }^{36}$ The Master (Sir James Chadwick), a physicist who had been a protégé of Lord Rutherford of Nelson in Manchester and later in Cambridge, ${ }^{37}$ was himself a Nobel Prize winner (awarded for proving the existence of the neutron). The senior Law Fellow was Sir Arnold (later Lord) McNair, first President of the European Court of Human Rights in Strasbourg, and later the President of the International Court of Justice at The Hague. Other members of the Fellowship who were either already hugely prominent in their disciplines or were later to become so included Professor Sir Ronald Fisher, the statistician and geneticist, Vincent (later Sir Vincent) Wigglesworth, the father of insect physiology, economist Peter (later Lord) Bauer, ${ }^{38}$ Michael Oakeshott, philosopher and political scientist and author of the work On Human Conduct and Joseph Needham, the Sinologist and author of Science and Civilization in China. ${ }^{39}$ In the year before Robin's election, Anthony Hewish had become a Fellow - he was to become a Nobel Laureate in 1974. This must have been a heady group with which to

32 This perhaps requires some qualification. Robin did not hold a position in the Law Faculty, that is as a Lecturer, Reader or Professor. His Fellowship of Caius gave him membership of the Faculty, but would not have entitled him (or obliged him) to give lectures or to examine for the Faculty.

33 Technically, admission to the Fellowship would not have entitled Robin to participate in the deliberations of the University in its debates in the Senate House as a member of "Regent House", since only graduates of the University were permitted to participate. Non-members of Cambridge who become Fellows are therefore awarded the MA degree. Volume VI of the Gonville and Caius Biographical History (Cambridge University Press, Cambridge, 1958) 398 records that Robin duly took the MA under Statute B III 6 in 1953.

34 It was Staircase N3, Tree Court, a building designed by the leading Victorian architect Alfred Waterhouse, with a splendid view down King's Parade. By good fortune, this was within about 100 metres of the University law library.

35 The College was initially founded by Edmund Gonville, a Norfolk priest, in 1348, and re-founded with the Royal permission of Queen (Bloody) Mary in 1557 by the Royal physician John Keys (who Latinised the spelling of his name to Caius).

36 Women were not admitted to the College as either students or Fellows until October 1979.

37 See CNL Brooke A History of Gonville and Caius College (Boydell, Woodbridge (Suffolk), 1985) 270.

38 Hungarian for "peasant" and the one of the more active participants in a divisive College coup in 1953 known as "The Peasants' Revolt". These battles were still discussed in awed tones when I became a Fellow in 1973.

39 Joseph Needham had the very rare distinction of having been elected both a Fellow of the Royal Society and then, having turned to history from science, to a Fellowship of the British Academy. 
mingle for a person whose principal intellectual companionship since leaving school had been in the law.

For all the eminence of its individual members, however, there was a degree of egalitarianism amongst the Fellows that the non-English might find rather surprising. Notwithstanding a period of intense political infighting amongst the members of the Fellowship in the early 1950s, which had undoubtedly produced an unhealthy degree of ill-feeling and resentment, ${ }^{40}$ Fellows were regarded as equals from the moment of election, whether they were teaching Fellows, Life Fellows, Professorial Fellows or (as in Robin's case) Research Fellows. ${ }^{41}$ One reason for this might well be that Fellows were in no sense reliant upon their College colleagues for further professional advancement within the university. All had a say and a vote in the affairs of the College at the termly General Meeting, and the vote was an equal one.

Added to that, there was an element of domesticity and comradeship amongst the members of the College. Fellows who chose to do so could have lunch together every day, and dinner was available every night, at High Table. The Fellows "combined" ${ }^{42}$ for dessert afterwards in a "the panelled room". ${ }^{43}$ Although primarily domestic occasions, Fellows were encouraged to bring in guests from both Cambridge and further afield, particularly visitors to the country. Notwithstanding the disparate fields of endeavour represented in the Fellowship, there were outlooks in common - a shared commitment to the life of the mind, the education of the young and the dispassionate pursuit of the truth. Again, this must have been an enormously liberating environment for a young man whose previous experience of university life had hitherto been so relatively limited.

Something of the flavour of the times can be captured by a reading of the so-called College "betting book", which (in addition to recording bets made between the Fellows) records incidents in the life of the College (and in some cases the life of the nation), some of which may be really rather whimsical, if not downright schoolboyish. By tradition, entries are made in it in manuscript by the most junior Fellow present. It is an ancient series of volumes; the entry for 21 March 1814 records that the President presented two bottles of wine "to celebrate the defeat of Buonaparte at Laon on the $9^{\text {th }}$ and $10^{\text {th }}$ of March."

40 Brooke, above n 37, 272.

41 Appointments to Research Fellowships were (and are) limited to a period of four years, and the principal obligation of such Fellows is that they will devote themselves full time to their research during that period. But it was not at all uncommon for Research Fellows who wished to pursue an academic career to become Teaching Fellows at some point during the four year period, and that carried far greater security of tenure, usually until the retiring age.

42 In a room known as the "combination" rather than "common" room. "Are you combining?" is still the common form of asking a colleague whether he or she intends to take dessert after dinner.

43 The room had been the College Library in 1432 but was remodelled in the $18^{\text {th }}$ century with the later addition of panelling taken from the wardroom of the battleship the "Duke of Wellington". 
Fellows who breached the informal set of rules by which the Combination Room was governed might be made to pay a forfeit or "fine", and there is an entry for 23 October 1953 that Mr Cooke "is fined for an act of inadvertence", almost certainly for starting to smoke before permission to do so had been given by the presiding Fellow. The "fine" for such transgressions was that the offender was required to pay for the next round of drinks (on that or a later occasion), and it was not wholly unheard of for somebody to commit a deliberate breach as a way of paying for the next round, or even for the presiding Fellow to fine himself for an (unspecified) "act of inadvertence".

Away from his books, Robin continued to pursue his interests in sport (and tennis in particular), playing with Philip Grierson, ${ }^{44}$ Michael Prichard ${ }^{45}$ and Peter Gray ${ }^{46}$ He also went to lectures in the Faculty and made friends with members of the Faculty including HWR (Bill) Wade who was then a Fellow of Trinity College, and Kurt Lipstein. ${ }^{47}$

\section{NEW ZEALAND OR CAMBRIDGE? THE ACADEMY OR PRACTICE?}

For family reasons, the Cookes decided to return to New Zealand early in 1955. Given that there were still nearly two years to run on the Fellowship, the possibility of a permanent post in the Faculty that surely beckoned and the obvious delight that Cambridge held for Robin, the decision is not entirely easy to understand and explain. The completion of the thesis at such speed would have been very draining, and the delights of the academic life might have begun to pall in the face of the reality of the conduct of supervisions and the marking of undergraduate essays. It is quite clear that when the young couple returned, they were contemplating doing so permanently. ${ }^{48}$ The death of his father in November 1956 (and perhaps the birth of a son Philip in February 1957) told against a decision to return to the academic life in England.

As is well known, Robin eschewed the safety net of practice as a solicitor on his return to Wellington, setting himself up immediately as a Barrister sole. Notwithstanding that his legal

44 Later Professor of Numismatics and Keeper of Coins at the Fitzwilliam Museum.

45 Michael Prichard was appointed to a Fellowship in Law in 1950, and at the time of writing is one of the most senior Fellows in the College, having been variously Director of Studies in Law from the time of his appointment until his retirement in September 1990. He had also been Senior Tutor and President of the College.

46 Became Professor of Chemistry at the University of Leeds, until he returned as Master in October 1988 upon the retirement of Sir William Wade.

47 Subsequently Professor Kurt Lipstein, who was one of the German Jewish émigrés who added so much to the cultural (legal) life of England after fleeing the possibility of Nazi persecution. He died in 2007, at the age of 96. See Jack Beatson and Reinhard Zimmerman (eds) Jurists Uprooted: German Speaking Emigré Lawyers in Twentieth Century Britain (Oxford University Press, Oxford, 2004) 463-482 and 749-760.

48 In letters of 9 August 1954 and again on 17 January 1955 (the latter written about a month before they embarked for New Zealand) to Bill Shires, Robin refers to making a decision about whether or not to remain permanently in New Zealand, and spending a bit of time there before making a decision. 
practice took off almost ${ }^{49}$ immediately, beginning his seemingly inevitable rise to great legal heights, the academic way of life continued to call. He understood academics and the academy generally and was tremendously supportive of them and their work. ${ }^{50}$ Not long after his return, he began writing for the New Zealand Law Journal, at that time one of the very few outlets for legal writing in New Zealand. In time, he produced a prodigious volume of extra-judicial material in the form of articles and lectures, culminating perhaps in the delivery of the Hamlyn Lectures, Turning Points of the Common Law. ${ }^{51}$ His last article was published in the Law Quarterly Review in 2006. ${ }^{52}$

The admiration and affection in which Robin held the College and the University were reciprocated. He was made an Honorary Fellow of Caius in 1982, an enormous honour at a time when there were only nineteen such Fellows in all. In 1990, the University paid him the tribute of an Honorary LLD. 53

In a letter written to Sir William Wade in 1987, Robin confessed that he sometimes dreamt of a semi-retirement spending a half year in Cambridge and a half year in New Zealand, simultaneously acknowledging as he mused that this was probably "a mirage". His elevation to the House of Lords in 1996 meant that London rather than Cambridge was necessarily his English base during his visits, but he also made possible a series of regular returns to the College that was for him always rather more than a stepping stone to the subsequent heights that he scaled with such apparently effortless panache.

49 There was the occasional hiccup, such as that when he acted as counsel on the losing side in Truth (NZ) Ltd $v$ Holloway [1961] NZLR 22 (PC).

50 See generally the tributes in many of the essays in Paul Rishworth (ed) Struggle for Simplicity in the Law: Essays for Lord Cooke of Thorndon (Butterworths, Wellington, 1997), especially Richard Sutton "Lord Cooke and the Academy: A View from the Law Schools" 13.

51 The four lectures were delivered in Cambridge, Oxford, de Montfort University and the Inner Temple, in 1996.

52 Rt Hon Lord Cooke of Thorndon "A Constitutional Retreat" (2006) 122 LQR 224.

53 "The other place" followed suit with a DCL the following year. Although Robin's primary allegiance was to Cambridge rather than Oxford, he had also spent some time as a visitor to Oxford. 
(2008) 39 VUWLR 